๑ Entomologica Fennica. 15 June 2001

\title{
Two dryinid species new for Fennoscandia with a re-evaluation of the generic division of N. European Gonatopodinae (Hymenoptera, Dryinidae)
}

\author{
Veli Vikberg \& Martti Koponen
}

Vikberg, V. \& Koponen, M. 2001: Two dryinid species new for Fennoscandia with a re-evaluation of the generic division of N. European Gonatopodinae (Hymenoptera, Dryinidae). — Entomol. Fennica 12: 33-38.

Bocchus vernieri Olmi, 1995 was found in Ta: Tammela, southern Finland, as the first species of the subfamily Bocchinae for Fennoscandia; it is a new species for N. Europe. Gonatopus horvathi Kieffer, 1906 is added to the fauna of Finland; it is also a new species for Northern Europe. The two species are further described on the basis of the new material. The generic position of North European species of Gonatopodinae is re-evaluated, and it is concluded that a single genus, Gonatopus Ljungh, should be recognized, to include two subgenera, Dicondylus Haliday (Haplogonatopus R. C. L. Perkins, syn. nov.) and Gonatopus s. str.

In the Appendix Bocchus italicus Olmi, 1984 is reported from Corfu as new to the fauna of Greece.

Veli Vikberg, Liinalammintie 11 as. 6, FIN-14200 Turenki, Finland; E-mail: veli.vikberg@mail.htk.fi

Martti Koponen, Department of Applied Biology, University of Helsinki, P.O. Box 27, FIN-00014 University of Helsinki, Finland; E-mail: martti.a.koponen@helsinki.fi

Received 18 January 2000, accepted 16 January 2001

\section{Introduction}

The larvae of Dryinidae are parasitoids of nymphs or more rarely adults of auchenorrhynchan Homoptera belonging to the superfamilies Cicadelloidea and Fulgoroidea (Gauld \& Bolton 1988). The dryinid fauna of Fennoscandia and Denmark was rather recently revised by Olmi (1994), who reported 34 species from the area. In this paper we now add two further species, one of them belonging to the subfamily Bocchinae which has not previously been reported from the area. These two rare species are further described on the basis of new material.

\section{Material and methods}

Dryinid specimens were studied under a Leitz stereomicroscope at magnifications of 50× and 100×; the light source was a halogen lamp $(12 \mathrm{~V}, 20 \mathrm{~W})$ with a light beam width of 10 degrees. The light was diffused by placing a piece of thick $(0.2 \mathrm{~mm})$ tracing acetate near the specimen. Measurements and drawings were made using a grid of squares $(50 \times 50$, side $0.20 \mathrm{~mm})$ in one eyepiece. Body part nomenclature follows Olmi (1994) and/or Goulet \& Huber (1993). 


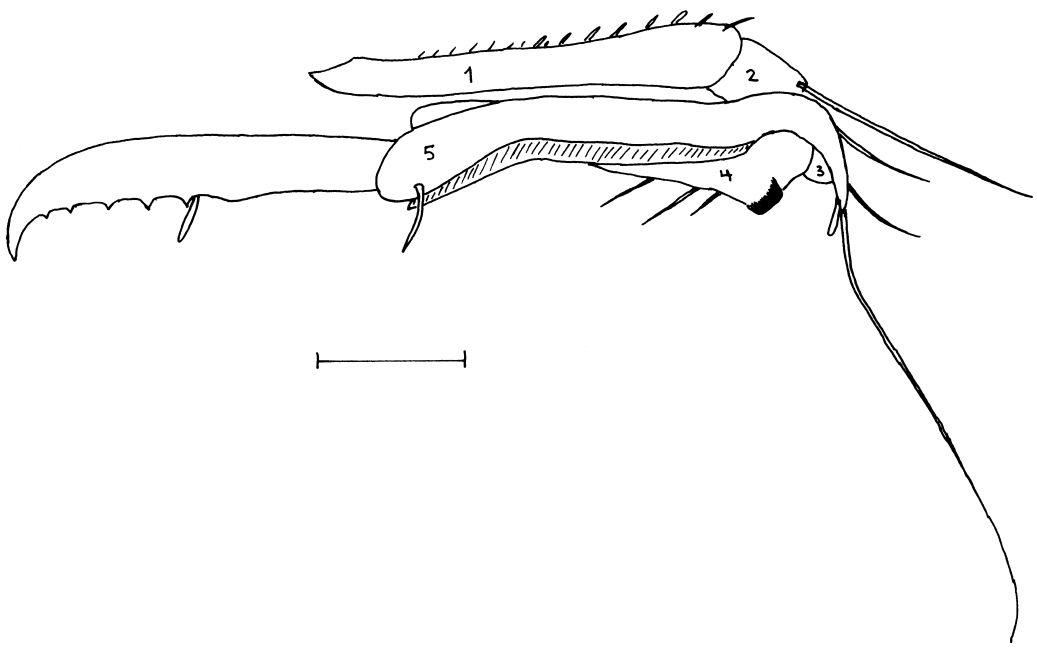

Fig. 1. Left fore tarsus of the female of Bocchus vernieri Olmi from Tammela, Finland, lateral (inner) view. - Scale line $0.1 \mathrm{~mm}$.

\section{Results}

\subsection{Bocchus vernieri Olmi (Bocchinae)}

Bocchus vernieri was described on the basis of a single female from Switzerland (Olmi 1995). The holotype was captured in Neuchâtel, Jura, Le Cachot, $1050 \mathrm{~m}$, in a sphagnum bog in August 1988. According to the collector, R. Vernier, the host is Ommatidiotus dissimilis (Fallén) (Homoptera, Issidae) which lives on Eriophorum vaginatum L. [as the author Kunze was given].

The Finnish female was swept on 8th July 1981, in Ta: Tammela, Grid 27 E 6740:322, M. Koponen leg. (DAZH). The collecting site was a small ditched swamp at or near the eastern border of the bog of Torronsuo, most of which is now a protected nature conservation area. The dominant plant in the collecting site was Eriophorum vaginatum. In Finland, Ommatidiotus dissimilis is the only member of Issidae, the host family on which Bocchus species are specialized (Olmi 1984). This planthopper is fairly seldom collected in Finland; it has been reported only from provinces Ab, N, St, Sa and Kb (Ossiannilsson 1978). Author MK has collected it from St: Kankaanpää and Rauma, and Om: Perho (coll. DAZH), but not from Ta: Tammela, although most probably it also occurs there.

Description of the Finnish female: Body length $2.64 \mathrm{~mm}$, head width $0.95 \mathrm{~mm}$. Head testaceous, frons and vertex mostly black, temporal orbit black. Lower face and clypeus yellowish brown, mandible brownish yellow. Scape testaceous, below paler, pedicel testaceous, flagellomere 1 testaceous - blackish brown, flagellum otherwise brownish black. Mesosoma black, with tegula testaceous. Legs testaceous, fore coxa and trochanter brownish yellow, hind coxa slightly infuscate. Petiole testaceous, gaster black.

Head dull, granulate. Lengths of antennal segments in $\mathrm{mm}$ : scape 0.253 , pedicel 0.152 , flagellomeres from base $0.202 ; 0.190 ; 0.177$; $0.177 ; 0.152 ; 0.139 ; 0.126 ; 0.202$. Ocelli small, POL 0.114; OL 0.089; OOL 0.233; OPL 0.139; TL $0.202 \mathrm{~mm}$.

Pronotum laterally longitudinally striate. Mesoscutum granulate, dull, notauli complete, their distance from each other behind $0.103 \mathrm{~mm}$. Propodeum: posterior surface rugose medially, with fine longitudinal carinae present only anteriorly. Micropterous; oval fore wing short $(0.20 \mathrm{~mm})$, reaching anterior margin of propodeum. Fore tarsus (Fig. 1): lengths of tarsomeres from base $0.329 ; 0.063 ; 0.063 ; 0.240 ; 0.304 \mathrm{~mm}$. Enlarged claw with one row of 5 teeth and one strong seta. Tarsomere 5 with a preapical lamella and an apical tooth.

The Finnish female agrees fairly well with the original description of the species. The female is characterized by mainly black coloration of the mesosoma and gaster and very short wings. It is the first representative of the subfamily Bocchinae in Fennoscandia. Its distribution is possibly boreoalpine but so far only two females have been captured. The male is still unknown. 
Specimens of Bocchus are rarely collected. Until now, the nearest capture has been in southern Slovakia from where the macropterous female of Bocchus slovacus was described by Strejček (1964). Later the same species was reported from Palanga, Lithuania (Ponomarenko 1978).

\subsection{Gonatopus horvathi Kieffer (Gonatopodinae)}

When Hellén (1953) discussed the dryinid fauna of Finland, he treated Gonatopus (Gonatopus) ljunghi Westwood and Gonatopus (Platygonatopus) pedestris Dalman as two quite different species. He wrote that G. pedestris differed from all other species by having a nearly flat vertex (excavated in others). Later Olmi and Currado (1977) designated the lectotype of Gonatopus pedestris Dalman, 1818 and synonymized Gonatopus ljunghii Westwood, 1833 with it. Therefore Vikberg (1986) listed G. pedestris of Hellén (1953) as Gonatopus sp. and, in the errata of Vikberg (1987), he mentioned that Gonatopus sp. should read G. horvathi Kieffer, 1906. Obviously nobody has noticed this fact. Olmi (1994) does not mention $G$. horvathi from Fennoscandia and Denmark at all.

Specimens of Gonatopus (Platygonatopus) pedestris sensu Hellén were studied in coll. W. Hellén, deposited in the Zoological Museum, University of Helsinki, with the help of Dr. Anders Albrecht. Hellén (1953) reported the species from two localities. Three females of G. horvathi from three localities, collected by W. Hellén, are now confirmed as new for North Europe.

Finland. (1) Ab: "Lojo", "4764” [pale yellow label; according to the notes of W. Hellén, collected on 15.8.1949 on the shore of the lake Lehmijärvi, which now belongs to Lohjan kunta/ Lojo kommun (669:34)], one female, body length $2.7 \mathrm{~mm}$, head width $0.72 \mathrm{~mm}$. (2) Sa: Joutseno, "3639" [yellow label; date 31.7.1949, on a dry hill], one female, body $2.7 \mathrm{~mm}$, head width 0.74 mm. (3) Kl: Parikkala, "5643" [pale yellowish label; there are two possibilities: if the label was originally yellow, the specimen was collected in Laurila (in Surumäki, 683:63) in a grove on 25.7.1940; if it was white, the specimen was collected in Muttilanmäki on 5.8.1945], one female, body $2.9 \mathrm{~mm}$, head width $0.76 \mathrm{~mm}$. The female from Parikkala bears also labels "pedestris Dalm." and "Gonatopus (Platygonatopus) pedestris Dalm." in Hellén's handwriting.

Further characters of Finnish females: Head black. Mandible, clypeus, malar space, lower anterior part of face and anterior part of gena yellow. Temple in two specimens brown. Scape, pedicel yellow, 3-5 basal flagellomeres pale brown, 3-5 apical ones dark brown.

Mesosoma black. Legs brownish yellow, upper side of fore coxa blackish, mid- and hind coxae mostly black. Thick parts of femora brownish black, hind surface of fore- and mid-tibia brownish.

Vertex flat, in frontal view lateral ocelli at the same level with upper margins of compound eyes. Meso-metapleural suture poorly defined. Fore tarsomere $11.63-1.69$ as long as tarsomere $4(\mathrm{n}=$ 2). Tarsomere 5 has an apical group of ca 10 lamellae and 16 basal lamellae in two rows (Fig. 2).

Using the key to females of Gonatopus species in Olmi (1994) specimens of G. horvathi would run to couplet 10 and possibly further to couplet 12 and clavipes (Thunberg). Couplet 10 could be changed, as follows:
10a First segment of fore tarsus 1.6-1.7 as long as fourth segment ....................................... horvathi Kieffer
- First segment of fore tarsus shorter or as long as fourth segment ...................................................... 10 b. $10 \mathrm{~b}=$ as couplet 10 in Olmi (1994).

Gonatopus horvathi was described from Krasova, Hungary (Kieffer, 1906). Later the same species was described from Kamjenka, Ljsvien, Perm, Russia as Cyrtogonatopoides borealis by N. G. Ponomarenko (1966); this was synonymized with G. horvathi by Olmi (1984). The distribution area of the species extends from the Pacific Ocean (Russian Far East and Sachalin), via Mongolia to Romania and southern Germany (Hilpert 1989). The nearest previous records of the species are about $1500 \mathrm{~km}$ from S. Finland. Psammotettix striatus (L.) is mentioned as the host (Ponomarenko 1978). According to Ossiannilsson (1983) the species named $P$. striatus in Finland is $P$. alienus (Dahlbom). Also the species which Rozvyazkina \& Pridantseva (1968) termed $P$. striatus is at least partly $P$. alienus. Hence the host of $G$. horvathi is probably Psammotettix alienus (Cicadellidae, Deltocephalinae), a vector of wheat dwarf virus.

The male of $G$. horvathi is unknown. For $G$. 


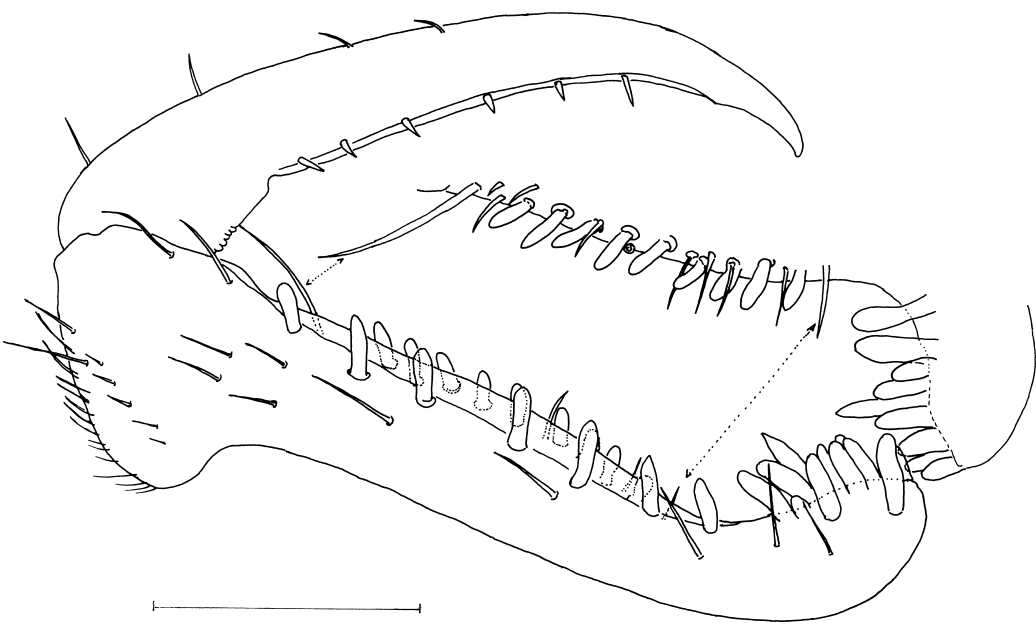

Fig. 2. Left chela of Gonatopus horvathi Kieffer, Lohja, Finland, lateral (outer) view. Insert: part in inner view to show the inner row of lamellae better; the arrows point to the same setae in two pictures. - Scale line $0.1 \mathrm{~mm}$. albifrons Olmi, 1994 the female is unknown. $G$. albifrons is known from southern Sweden, but not yet from Finland, and it has been reared in France from a species of Delphacidae (Olmi 1994); consequently it seems improbable that $G$. albifrons could be the male of $G$. horvathi.

\subsection{On the genera and subgenera of Gonatopo- dinae in Northern Europe}

The generic division of Gonatopodinae is problematic (Olmi 1984). The North European species were divided into six genera by Olmi (1984), but into only two by Olmi in 1994: Haplogonatopus R. C. L. Perkins (type species $H$. apicalis Perkins) and Gonatopus Ljungh (type species $G$. formicarius Ljungh), which differ only in the number of labial palpal segments (one in the former and two or three in the latter), a character that is difficult to observe. If the female of Haplogonatopus oratorius (Westwood) is studied using the key to females of Gonatopus in Olmi (1994), it would run to couplet 3 and to G. helleni Raatikainen by colour characters. In fact, the chelae of these two species and of G. bicolor (Haliday) are very similar, and all three species have been reared from species of Delphacidae. They share one common recorded host, Megadelphax sordidulus (Stål). It seems that the number of palpal segments is not a suitable character at generic level and it would be better to synonymize these two genera. The number of labial and maxillary palpal segments varies even within some species of Gonatopus (Olmi 1994).

We propose that a more practical and perhaps more natural division would be to recognise the single genus Gonatopus Ljungh with two subgenera:

1. Subgenus Dicondylus Haliday (type species Dryinus bicolor Haliday) (including Pseudogonatopus R. C. L. Perkins (type species $P$. kurandae Perkins), Haplogonatopus R. C. L. Perkins (type species H. apicalis Perkins), syn. nov. and Donisthorpina Richards (type species D. formicicola Richards)). It is characterized by an enlarged claw of the female fore tarsus having a larger tooth quite near the apex (= species nos 21-27 in Olmi 1994). Its hosts belong to Delphacidae (on the basis of the host, G. albifrons belongs here).

2. Subgenus Gonatopus s. str. (type species $G$. formicarius Ljungh) (including Platygonatopus Kieffer (type species Gonatopus planiceps Kieffer) and Tetrodontochelys Richards (type species Gonatopus ljunghii Westwood)). It is characterized by an enlarged claw having a shallow small tooth a little further from the apex (= species nos 28-34 in Olmi 1994 and G. horvathi). Its hosts are species of Cicadellidae.

At present, males cannot be divided into these subgenera by any character. 
Acknowledgements. We thank Anders Albrecht for loaning the specimens of Gonatopus pedestris from Wolter Hellén's collection. Mark Shaw and two anonymous referees commented on the manuscript and suggested several improvements. Mark Shaw improved our English.

\section{References}

Gauld, I. \& Bolton, B. (eds.) 1988: The Hymenoptera. British Museum (Natural History), Oxford University Press, pp. 1-332.

Hellén, W. 1953: Übersicht über die Bethyliden und Dryiniden Finnlands. — Notulae Entomol. 33: 88-102.

Hilpert, H. 1989: Zum Vorkommen einiger Dryiniden in Südwestdeutschland sowie Bemerkungen zu Embolemus ruddii Westwood, 1833 (Hymenoptera, Bethyloidea, Dryinidae, Embolemidae). — Spixiana 11(3): 263-269.

Kieffer, J.-J. \& Marshall, T. A. 1906: Proctotrypidae. In André, E. (Ed.): Species des Hyménoptères d'Europe et d'Algerie 9, pp. 289-552.

Nast, J. 1972: Palaearctic Auchenorrhyncha (Homoptera), an annotated check list. - Warszawa, $550 \mathrm{pp}$.

Olmi, M. 1984: A revision of the Dryinidae (Hymenoptera). - Memoirs of the American Entomological Institute 37, pp. I-XII, 1-1913.

Olmi, M. 1994: The Dryinidae and Embolemidae (Hymenoptera: Chrysidoidea) of Fennoscandia and Denmark. - Fauna Entomol. Scandinavica 30, 1-98.

Olmi, M. 1995: Contribution to the knowledge of the world Dryinidae (Hymenoptera Chrysidoidea). — Phytophaga 6: 3-54.

Olmi, M. \& Currado, I. 1977: On the identity of Gonatopus pedestris Dalman (Hymenoptera, Dryinidae). -
Entomol. Scandinavica 8: 76-78.

Ossiannilsson, F. 1978: The Auchenorryncha (Homoptera) of Fennoscandia and Denmark. Part 1: Introduction, infraorder Fulgoromorpha. - Fauna Entomol. Scandinavica 7(1): 3-222.

Ossiannilsson, F. 1983: The Auchenorrhyncha (Homoptera) of Fennoscandia and Denmark. Part 3: the family Cicadellidae: Deltocephalinae, Catalogue, Literature and Index. - Fauna Entomol. Scandinavica 7(3): 594979.

Ponomarenko, N. G. 1966: New Gonatopodinae of the USSR fauna (Hymenoptera, Dryinidae). - Zool Zh. 45, 1578-1580 [In Russian]

Ponomarenko, N. G. 1978: Family Dryinidae. In: Trjapitzyn, V. A. (ed.), Keys to the insects of the European part of USSR 3. Hymenoptera, part 2. Publ. House Nauka, Moscow, pp. 16-27. [In Russian; translated in English, E. J. Brill, Leiden 1988]

Rozvyazkina, G. M. \& Pridantseva, E. A. 1968: Leafhoppers of the group Psammotettix striatus L. (Homoptera, Cicadellidae) - vectors of virus diseases of cereals, their systematics and distribution. - Zool. Zh. 47: 690696 [In Russian]

Strejček, J. 1964: Eine neue Art der Gattung Bocchus Ashm. aus der Tscheckoslowakei (Hym., Dryinidae). — Acta societatis entomologicae čechosloveniae 61(4): 323326.

Vikberg, V. 1986: A checklist of aculeate Hymenoptera of Finland (Hymenoptera Apocrita Aculeata). — Notulae Entomol. 66: 65-85.

Vikberg, V. 1987: Enumeratio insectorum fenniae Hymenoptera, Apocrita Aculeata. - Entomological Exchange Association in Helsinki, Printaco Ky, Helsinki. pp. I-IV, 61-85. 


\section{Appendix}

\section{Bocchus italicus Olmi found in Corfu, Greece (Hymenoptera, Dryinidae).}

Bocchus italicus was described from Lido, Venezia, Italy, based on one female (Olmi 1984). A second female was found by author MK in Benitses, Corfu, Greece on 25 May 1981. It is deposited in coll. DAZH.

The characters of the Greek female are: Length of body $2.3 \mathrm{~mm}$, head width $0.78 \mathrm{~mm}$. Entirely reddish yellow-yellowish brown, mandible paler. Ovipositor sheath dark brown. Last abdominal terga retracted inside gastral tergum 2 and appearing darker.

Vertex dull, granulated, frons faintly granulate, subshining. Lengths of antennal segments in mm: scape 0.202 , pedicel 0.147 , flagellomeres from base $0.190 ; 0.152 ; 0.126 ; 0.126 ; 0.119 ; 0.126 ; 0.114$; 0.177. Ocelli small, POL 0.106, OL 0.056, OOL 0.177, OPL 0.147 and TL $0.172 \mathrm{~mm}$. Mandible 4dentate, second tooth (counted from lower margin) very small.

Fore tarsus (Fig. 3): lengths of tarsomeres from base 0.329; 0.040; 0.071; 0.202; $0.253 \mathrm{~mm}$. Enlarged claw with one row of 6 teeth and a large modified bristle. Tarsomere 5 with one preapical lamella and two small bristles.

Brachypterous; forewing $(0.8 \mathrm{~mm})$ reaching to tergum 1 of gaster, with pterostigma hardly developed, linear.

The characters fit the original description of the species rather well. The species is new for Greece as Olmi (1984) mentions no species of Bocchus from Greece. The male is unknown.

Possibly the host of the species is Aphelonema quadrivittata (Fieber, 1876), which was collected in Corfu in 1977, 1978 and 1981 by author MK, also from the place of capture of B. italicus. The size of this issid planthopper is about the same as that of Ommatidiotus dissimilis (Fallén), the host of $B$. vernieri Olmi. According to Nast (1972), Aphelonema quadrivittata is found in Albania, Austria, Hungary, Italy, Tadzhikistan and Yugoslavia, but it seems not yet to have been recorded from Greece.

For the literature cited, see References.

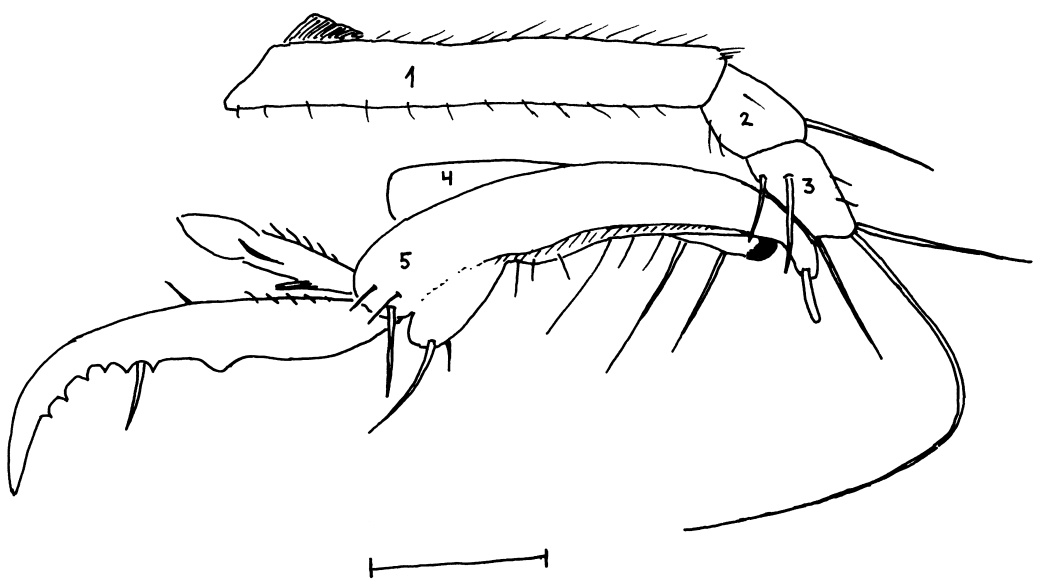

Fig. 3. Left fore tarsus of the female of Bocchus italicus Olmi from Corfu, Greece, lateral (inner) view. - Scale line 0.1 $\mathrm{mm}$. 